\title{
The Socio-Cultural Determinants of Begging: A Case Study of Karachi City
}

\author{
Dr. Sakina Riaz, \\ Corresponding author, Assistant Professor, Department of Social Work, University of Karachi, Pakistan.
}

Dr. Mumtaz Ali Baloch,

Chairperson/Associate Professor, Department of Social Work, University of Balochistan, Quetta,Pakistan.

\begin{abstract}
The present research paper aims to find out the socio-economic status of beggars' in Karachi city. A descriptive research design was employed by using survey method. The primary source of data collection was face to face interviews. A sample of 140 street beggars, were selected from different public places using purposive, a non-probability sampling technique.Data analysis, chi- square test of association was done. The key findings of the study show that begging is a structured profession in the city. Data indicated that the majority of the respondents have their own houses and they become the professional beggar in a routine with high satisfaction their existing profession. This study suggests that there is an urgent need to design and implement a comprehensive urban policy in order to control and the begging practice in the city.
\end{abstract}

Keywords: Socio-Cultural Determinants, Begging practice, Karachi.

DOI: $10.7176 / \mathrm{JESD} / 10-11-09$

Publication date: June $30^{\text {th }} 2019$

\section{INTRODUCTION}

ILO (2004) defined begging is defined as: "a range of activities whereby an individual asks a stranger for money on the basis of being poor or needing charitable donations for health or religious reasons. Beggars may also sell small items, such as dusters or flowers, in return for money that may have little to do with the value of the item for sale." Generally, beggars have seen in all the period of human societies for getting assistance or charity in order to full fill their human survival needs. Currently, begging has become a profession, especially in the urban lifestyle due to many pull factors supported by urbanization which urged people to move towards better socio-economic opportunities, this trend also promotes begging occurrence (Gurav, 2015).Yet, there are numerous people who deliberately has chosen begging. Indeed, begging is a very complexed phenomenon and has stayed in almost every society, whereas its dominance is different from culture to culture.

It is very difficult to explain that why people choose this activity. There is not a specific single reason which is related to begginning, still, it has different reasons and ground for its continuing practice in diversified culture. It is the consequence of a variety of socio-economical and biological aspects. Though, the tradition of begging has long roots in different culture and closely associated with religion particularly in South Asia for instance in India, where charity is measured one of the noblest human quality according to Hindu tradition (Dhruvasan 1963, P:10-12). In various religions like in Islam, Christianity and even in Hinduism seeking alms is an opportunity to earn God's blessings (Kaushik,2014). This situation becomes more critical if any beggar has been suffering from any chronic disease like leprosy and mental illness, it tacitly criminalizes the illnesses (Mander, 2009).

Beggars use a number of strategies to take money from others and have countless explanations for hunting other's assistance. In Pakistan, it is a traditional mindset which generally promotes begging practices in urban areas like Karachi.Mostly, in Karachi, cultural practices promotes begging. For example, certain religious groups 
or social classes may believe that the financial support of a needy person is a noble job. It has been observed by the researcher, that people who involve in begging is more often continue to work as a professional beggar and do not join any respectable profession.

\section{LITERATURE REVIEW}

Begging has been initiated as social practice since the existence of human society. It is viewed as one of the oldest challenges for human society. Though, there is no any evidence is revealed that begging is existed in primitive societies due to close social ties and strong family sytem (Khan,2013) and the weaker social structure and family support system had the foundation of begging as a social problem. Historically, Begging had noted in Greece amongst the initial period and the Byzantine era (Johnny, 2008) \& (Alan,2010). The begging was popularized in the purview of the Christian doctrine of almsgiving during the era of the Middle Ages.(Tatek A.,2009).

Earlier researches on developing and developed countries suggest that socio-cultural such as migrant background, low educational level, and workload has played significant influences in determining the practice of begging. In this regards, a variety of an arguments and questions may arise in analyzing the process of begging [see also Jelili, (2013), Ghimire Loknath,(2014) Hanchao Lu ,(2005), Olawale, S.G.(2007), Yusuf A. Bell M. B, Jarimi M, Ahmed S. Ogungbade O.K, J. A. Omotosho, AlHassan. Y. S(2012), Ahamdi H.(2010)].

Several research reviews have been published on begging behavior.For instance, (Tripathi and Arora, 2010) had viewed begging as soliciting or receiving alms in public place by exposing wound, injury, deformity or disease whether of himself or of any other person or animal. Nevertheless, Begging is very critical and complex in nature. It is observed that voluminous tactics have been used by beggars for begging. For example, a sick young street beggar generally attracts the sympathy of the common man (Fives, et al; 2010). Tanvir (2001) noticed that many beggars used different strategies to attract people. For example, women with very young babies in their laps cause people to give them alms. Broun (2010) considered begging as a charge for the failure or fragile governance in several cultures (Usoro, 2007;Bose and Hwang 2002; Collins and Blomley,2003), observed begging as the practice of pleading others to provide financial support like money, clothes or food with no anticipation of exchange or refund. Boaten (2006), and Yilmaz and Dülgerler (2011) noted that "street children and begging as an ordinary phenomenon".

Some scholars considered begging as " an act of stopping people on the street to beg for assistance" Chukwulobe (2011) and some people choose it as an occupation (Ogunkan and Fawole, 2009; Adedibu and Jelili, 2011). It frequently happens for obtaining a monetary assistance, usually in cash or charitable contribution without doing any services in return(John, 2010; Balogun,2012).

However, many kinds of researchers supported that begging has a strong association with poverty, for instance, the research of Khan et.al., (2014). There are many begging groups who coerced common people into begging or some people are forced to beg (Sabina, 2010) and keep the profit or take their share. It is viewed that these groups are generally supervised by "businessmen" or criminal gangs or mafias. Most of them are living in a very bad situation, the risk of maltreatment, forcefulness or even the assassination too. (Saini,2009, Malone, 2009). Simillarliy, Tambawal, (2010), Namwata et al. (2012), Adedibu, (1989) have mentioned that there is a strong link between deviant behaviors and street begging. Evidently, it is important to notice that the efforts on criminalizing and forbidding or arresting beggars have not evidenced mostly operative (Lynch, 2005; Rahman, 2009; Johnsen and Fitzpatrick, 2008).

In a study conducted by Abdallah Jacob Seni (2016) suggested that training is required for "influential community members" in controlling begging practices. In a report conducted by Europen Commission, published in 2012, had viewed the typology of the child begging into "Social and legal context" and classified into six categories ,which are focusing characteristics of children;begging Situation;begging activities; age group;child trafficking, and begging as Family survival Strategy .

As per the Government of Pakistan report of 2010 "the estimated population of Pakistan to be $171,297,000$ with approximately $32.5 \%$ living in urban and $67.5 \%$ in rural areas." (Nafees A. et al,2012). The Constitution of Pakistan has confirmed the provision of welfare is the responsibility of the State and declared that "The state shall provide for all persons employed in the service of Pakistan or otherwise, social security by compulsory social insurance or other means; and provide basic necessities of life". The clause c \& d of article 38 of the constitution has endorsed that the provision of social safety net is the state's job.However in the Pakistani 
context ,the human development indicators are quite alarming. Though, there is an upturn trend of begging is commonly observed particularly in urban areas of Pakistan.

While there is no precise record is available about beginning practices and therefor, due to the dire shortage of the record, it is very difficult to define the history of begging in Pakistan and on what reasons it has originated in urban areas of the Country? Certainly, there are a number of social-cultural and political and environmental factors that involved promoting begging in urban areas. The scope of the present study is restricted to Karachi, the mega and one of the rapidly growing cities of Pakistan. According to the World Population Review report:

"In the last few decades and the metropolitan area have more than 23 million people, with a population density of over 24,000 people per square kilometer, or 63,000 per square mile ... and nearly 5 million people, or $50 \%$ of the population, in $2000 . "$

Similarly, it has been estimated that by the year 2025, more than 60 percent of the world's population will live in urban areas (Benítez, 2001).Keeping in view this scenario, through this research, an attempt has been made to find out the socio-economic cause of beggars with reference to Karachi. In the formal sector more than 4,500 industrial units are working whereas there is no research statistic has been accessible for the informal sector in Karachi. Hasan A, Mohib M. (2003) had viewed the city as per categorization of residence, and described into planned or unplanned areas ('katchi abadis' or 'Goths'). There are an estimated 702 squatter settlements, or 'ketchup abides,' in the city harboring 40 to 61 percent of the population (Nafees A. etal, 2012).

The researcher has implied functionalist perspective and Nurkse's vicious circle of poverty as a theoretical framework to understand the paradox of begging in Karachi in this study. The first was discusses the function of social institutions and social order and argues that "social stratification is needed to encourage people with distinct intelligence, knowledge, and skills to enter the most important occupations". The second one focused on a "circular constellation of forces tending to act and react in such a way as to keep a country in the state of poverty" the help to understand the existence of begging across the generations (Jelili, 2006) \& (Ogunkan and Fawole, 2009).

\subsection{Objectives of the Study}

This study was undertaken to identify the socio-economic status of street beggars in Karachi. Following study objectives were prepared for this research:

to explore the socio-economic characteristics of the street beggars in Karachi;

to investigate the extent to the association between socioeconomic and cultural

Factors that influence the begging among beggars in Karachi;

to determine the practices and the life patterns of beggars in Karachi;

to examine the beggar satisfaction with beggary as the profession.

\subsection{Hypothesis}

1. There is a significant relationship between the ethnic background of the Beggars and their level of education

2. There is a significant relationship between residing conditions and begging as a Profession.

3. There is a significant relationship between methods and practices of begging \& daily income of the beggar.

4. Beggars are eager to suggest their children adopt the same profession in future.

\subsection{The significance of the Study}

The study has manifolds importance as it provides information about the beggar's lifestyle and helps to understand their socio-economic status. It will also help to understand the phenomena of begging and explain the Beggar's perspective regarding begging practices as a profession in Karachi city. This study was limited to the inner-city area of the city. 


\subsection{Methodology}

Due to the non-availability of exact statistics about beggars living in Karachi, it was a great challenging for the researcher to find out the actual number of beggars living or working on the street in Karachi and conducts the research on the topic.Hence; a quantitative method was used for data collection for this study.

A sample of one hundred and forty $(n=140)$ street beggars was obtained from numerous public places mostly shopping places in the urban areas of Karachi, with the help of informal contacts, accompanied by taking informed consent from the participants. This sample fulfills several criteria for this research. First, the respondents are living and working as professional beggars in Karachi. Second, they ensure a sound representation of the all provinces of Pakistan in terms of population as well as the socio-economic background. Only those beggars were included who have been engaged in begging since last two to three years in the city.

The data were collected within these pre-fixed strata through field survey in the commercial areas of six study sites which includes Gulshan-e-Iqbal block 4, Gulistan-e-Johar block 13\& 14, Clifton, NorthNazim Abad, Hyderi Market, and Tariq Road; represented high and lower-middle-income vicinity of the city. By using purposive convenient sampling technique, the sample was collected through face to face interviewed method for data collection from respondents. A especially aimed questionnaire was used as a data collection tool in this study.

The data was analyzed and the Pearson Chi-Square test. Four null hypotheses were raised and tested at 0.05 level of significance by using Statistical Package for Social Sciences (SPSS) version 16.0 for windows.

\subsubsection{Demographic Distribution of the Respondents Table 1}

\begin{tabular}{|c|c|c|c|}
\hline Gender & Frequency & Percent & Valid Percent \\
\hline Male & 55 & 38.7 & 39.3 \\
\hline Female & 59 & 41.5 & 42.1 \\
\hline Transgender & 26 & 18.3 & 18.6 \\
\hline Total & 140 & 98.6 & 100.0 \\
\hline Age & Frequency & Percent & Valid Percent \\
\hline 60 \& above & 15 & 10.6 & 10.7 \\
$55-60$ & 16 & 11.3 & 11.4 \\
$50-55$ & 11 & 7.7 & 7.9 \\
$45-50$ & 10 & 7.0 & 7.1 \\
$35-40$ & 6 & 4.2 & 4.3 \\
$30-35$ & 34 & 23.9 & 24.3 \\
$25-30$ & 13 & 9.2 & 9.3 \\
$20-25$ & 35 & 24.6 & 25.0 \\
Total & 140 & 98.6 & 100.0 \\
\hline Religion & Frequency & Percent & Valid Percent \\
\hline Muslim & 92 & 64.8 & 65.7 \\
Hindu & 35 & 24.6 & 25.0 \\
Others & 13 & 9.2 & 9.3 \\
Total & 140 & 98.6 & 100.0 \\
& & &
\end{tabular}




\begin{tabular}{|c|c|c|c|}
\hline $\begin{array}{c}\text { Income (per } \\
\text { day) }\end{array}$ & Frequency & Percent & Valid Percent \\
\hline Rs:100-150 & 4 & 2.8 & 2.9 \\
\hline Rs $151-250$ & 9 & 6.3 & 6.4 \\
\hline Rs $251-400$ & 22 & 15.5 & 15.7 \\
\hline Rs:401-550 & 22 & 15.5 & 15.7 \\
\hline Rs:550-700 & 39 & 27.5 & 27.9 \\
\hline $\mathrm{R}: \mathrm{s} 701-850$ & 23 & 16.2 & 16.4 \\
\hline Rs: $850-1000$ & 21 & 14.8 & 15.0 \\
\hline Total & 140 & 98.6 & 100.0 \\
\hline Marital Status & Frequency & Percent & Valid Percent \\
\hline Married & 51 & 35.9 & 36.4 \\
\hline Unmarried & 34 & 23.9 & 24.3 \\
\hline $\begin{array}{l}\text { Married with } \\
\text { children }\end{array}$ & 29 & 20.4 & 20.7 \\
\hline $\begin{array}{l}\text { Married without } \\
\text { children }\end{array}$ & 10 & 7.0 & 7.1 \\
\hline $\begin{array}{l}\text { Unmarried with } \\
\text { children }\end{array}$ & 16 & 11.3 & 11.4 \\
\hline Total & 140 & 98.6 & 100.0 \\
\hline $\begin{array}{c}\text { Ethnic } \\
\text { Background }\end{array}$ & Frequency & Percent & Valid Percent \\
\hline Urban & 33 & 23.2 & 23.6 \\
\hline Rural & 94 & 66.2 & 67.1 \\
\hline Others & 13 & 9.2 & 9.3 \\
\hline Total & 140 & 98.6 & 100.0 \\
\hline Qualification & Frequency & Percent & Valid Percent \\
\hline Primary & 37 & 26.1 & 26.4 \\
\hline Secondary & 25 & 17.6 & 17.9 \\
\hline Matric & 39 & 27.5 & 27.9 \\
\hline Illiterate & 23 & 16.2 & 16.4 \\
\hline Intermediate & 11 & 7.7 & 7.9 \\
\hline
\end{tabular}




\begin{tabular}{|c|c|c|c|}
\hline $\begin{array}{c}\text { Graduate and } \\
\text { above } \\
\text { Total }\end{array}$ & $\begin{array}{c}5 \\
140\end{array}$ & $\begin{array}{r}3.5 \\
98.6\end{array}$ & $\begin{array}{c}3.6 \\
100.0\end{array}$ \\
\hline Satisfaction & Frequency & Percent & Valid Percent \\
\hline Satisfied & 45 & 31.7 & 32.1 \\
\hline Not Satisfied & 58 & 40.8 & 41.4 \\
\hline $\begin{array}{c}\text { Up to some } \\
\text { extent Satisfied }\end{array}$ & 26 & 18.3 & 18.6 \\
\hline No Answer & 11 & 7.7 & 7.9 \\
\hline Total & 140 & 98.6 & 100.0 \\
\hline Profession & Frequency & Percent & Valid Percent \\
\hline $\begin{array}{c}\text { Treat as the full- } \\
\text { time job. }\end{array}$ & 36 & 25.4 & 25.7 \\
\hline $\begin{array}{l}\text { Working as Part- } \\
\text { time job }\end{array}$ & 51 & 35.9 & 36.4 \\
\hline $\begin{array}{c}\text { Working as } \\
\text { seasonal beggar }\end{array}$ & 29 & 20.4 & 20.7 \\
\hline $\begin{array}{l}\text { working as } \\
\text { occasional } \\
\text { beggar }\end{array}$ & 24 & 16.9 & 17.1 \\
\hline Total & 140 & 98.6 & 100.0 \\
\hline $\begin{array}{l}\text { Practice } \\
\text { /Method }\end{array}$ & Frequency & Percent & Valid Percent \\
\hline By using Slogan & 20 & 14.1 & 14.3 \\
\hline $\begin{array}{c}\text { Through Silent } \\
\text { Request }\end{array}$ & 20 & 14.1 & 14.3 \\
\hline By Showing Art & 20 & 14.1 & 14.3 \\
\hline $\begin{array}{l}\text { By displaying } \\
\text { Animals } \\
\text { (monkey) }\end{array}$ & 13 & 9.2 & 9.3 \\
\hline $\begin{array}{l}\text { By showing their } \\
\text { weak or small } \\
\text { children }\end{array}$ & 26 & 18.3 & 18.6 \\
\hline $\begin{array}{c}\text { By showing their } \\
\text { disability } \\
\text { /injured body } \\
\text { part }\end{array}$ & 19 & 13.4 & 13.6 \\
\hline $\begin{array}{l}\text { By showing their } \\
\text { medical reports } \\
\text { or prescriptions }\end{array}$ & 22 & 15.5 & 15.7 \\
\hline Total & 140 & 98.6 & 100.0 \\
\hline
\end{tabular}




\begin{tabular}{c|c|c|c|}
\hline $\begin{array}{c}\text { Residential } \\
\text { Status }\end{array}$ & Frequency & Percent & Valid Percent \\
\hline $\begin{array}{c}\text { living in own } \\
\text { property } \\
\text { living in Own }\end{array}$ & 29 & 20.4 & 20.7 \\
$\begin{array}{c}\text { property in slum } \\
\text { areas } \\
\text { Living as a }\end{array}$ & 38 & 26.8 & 27.1 \\
$\begin{array}{c}\text { tenant in a rented } \\
\text { house } \\
\text { Living with } \\
\text { relatives. } \\
\text { Total }\end{array}$ & 32 & 22.5 & 29.3 \\
& 140 & 98.6 & 100.0
\end{tabular}

\subsection{Discussion \& Results}

\section{Testing of Hypotheses (Table: 2)}

1. Ho: There is a significant relationship between the ethnic background of the beggars and their level of education.

\section{Chi-Square Tests}

\begin{tabular}{|l|l|l|l|}
\hline & Value & Df & Asymp. Sig. (2-sided) \\
\hline Pearson Chi-Square & $6.068^{\mathrm{a}}$ & 10 & .810 \\
Likelihood Ratio & 7.558 & 10 & .672 \\
Linear-by-Linear Association & .674 & 1 & .412 \\
N of Valid Cases & 140 & & \\
\hline
\end{tabular}

a. 9 cells $(50.0 \%)$ have expected count less than 5. The minimum expected count is .46 . 


\section{Bar Chart}

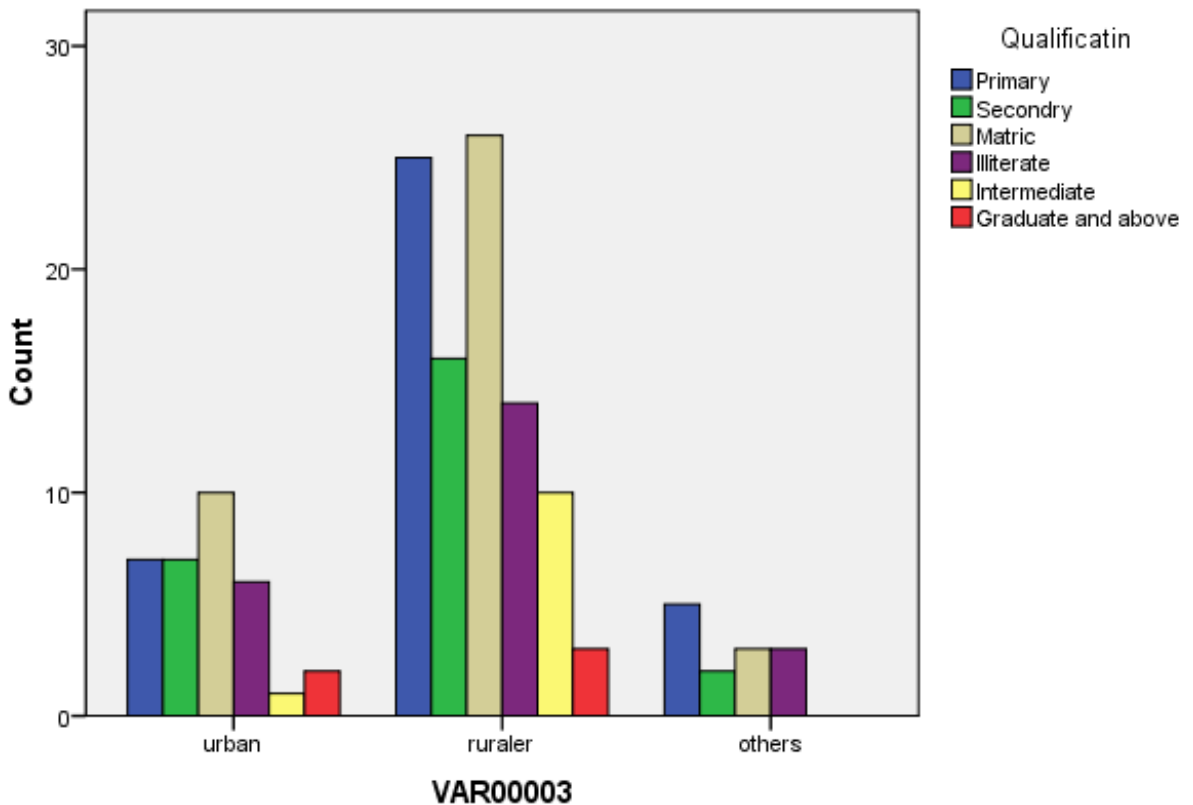

Figure : 1

The above table indicates that $\chi(1)=: 6.068^{\mathrm{a}} \quad \mathrm{p}=0.810$

It is revealed from the interpretation of the data that there was no significant association between qualification of the beggars and there ethnic background. In this case, $\mathrm{phi}=.810$, which is a weak positive relationship between the two variables. So, it can be conclude that we reject the null hypothesis and accept our alternative hypothesis.

Testing of Hypothesis No:2

Ho: There is a significant relationship between residing conditions and begging as a profession.

Chi-Square Tests

\begin{tabular}{|c|c|c|c|c|c|c|c|c|c|}
\hline & & \multirow[b]{3}{*}{$\mathrm{df}$} & \multirow{3}{*}{$\begin{array}{c}\text { Asymp. } \\
\text { Sig. (2- } \\
\text { sided) }\end{array}$} & \multicolumn{3}{|c|}{ Monte Carlo Sig. (2-sided) } & \multicolumn{3}{|c|}{ Monte Carlo Sig. (1-sided) } \\
\hline & & & & \multirow[b]{2}{*}{ Sig. } & \multicolumn{2}{|c|}{$\begin{array}{l}99 \% \text { Confidence } \\
\text { Interval }\end{array}$} & \multicolumn{2}{|c|}{$\begin{array}{l}\text { 99\% Confidence } \\
\text { Interval }\end{array}$} & \multirow[b]{2}{*}{ Sig. } \\
\hline & & & & & $\begin{array}{l}\text { Lower } \\
\text { Bound }\end{array}$ & $\begin{array}{l}\text { Upper } \\
\text { Bound }\end{array}$ & $\begin{array}{l}\text { Lower } \\
\text { Bound }\end{array}$ & $\begin{array}{l}\text { Upper } \\
\text { Bound }\end{array}$ & \\
\hline Pearson Chi-Square & $9.984^{\mathrm{a}}$ & 9 & .352 & $.360^{\mathrm{b}}$ & .347 & .372 & & & \\
\hline Likelihood Ratio & 10.344 & 9 & .323 & $.352^{\mathrm{b}}$ & .340 & .364 & & & \\
\hline Fisher's Exact Test & 9.981 & & & $.351^{\mathrm{b}}$ & .339 & .363 & & & \\
\hline $\begin{array}{l}\text { Linear-by-Linear } \\
\text { Association }\end{array}$ & $1.984^{\mathrm{c}}$ & 1 & .159 & $.162^{b}$ & .153 & .172 & .077 & .092 & $.084^{\mathrm{b}}$ \\
\hline $\mathrm{N}$ of Valid Cases & 140 & & & & & & & & \\
\hline
\end{tabular}

1 cells $(6.3 \%)$ have expected count less than 5 . The minimum expected count is 4.97 . ( $\mathrm{p}$ value : $\mathbf{0 . 3 5 2}$ ) 


\section{Bar Chart}

\section{Bar Chart}

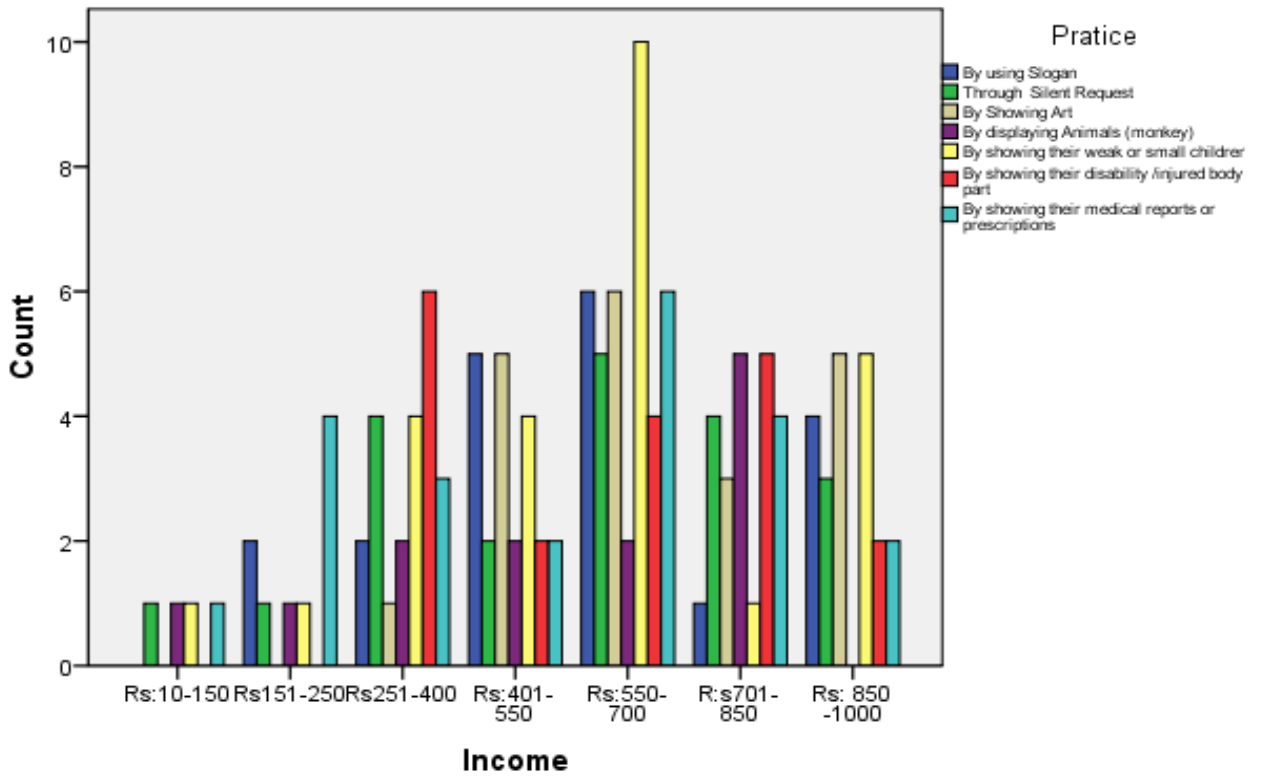

Figure :2

Another finding is that majority of that respondents who have their own house in the city, worked as a part-time profession (34.5\%). Whereas, $28.9 \%$ of the full time beggars have their own houses in slums areas. This result tells us that there is statistically significant association between residing conditions and begging as a profession in the present study.

Testing of Hypothesis No:3

There is a significant relationship between methods and practices of begging $\&$ daily income of the beggar.

Chi-Square Tests

\begin{tabular}{|c|c|c|c|}
\hline & Value & Df & Asymp. Sig. (2-sided) \\
\hline Pearson Chi-Square & $36.346^{\mathrm{a}}$ & 36 & .453 \\
Likelihood Ratio & 40.596 & 36 & .275 \\
$\begin{array}{c}\text { Linear-by-Linear } \\
\text { Association }\end{array}$ & .936 & 1 & .333 \\
N of Valid Cases & 140 & & \\
\hline
\end{tabular}

a. 43 cells $(87.8 \%)$ have expected count less than 5 . The minimum expected count is .37 .(p value : $\mathbf{0 . 4 5 3 )}$

\section{figure : 3}

The result indicates that a high majority of the respondent earns Rs: 550-700 per day. The respondents disclosed that showing weak or small children (their own or borrowed) as a good strategy to earn money in this profession. The beggars used a number of strategies in order to earn more in an organized manner for instance the results 
shows the second heights percentage of the beggars used as showing their medical reports or prescription and earns in between the range of Rs: 250 - 1000 per day. The data shows that using Slogan, using salient request and showing art are popular practices whereas displaying animals (monkey, birds etc.) as the unpopular or weakest method of begging in the study areas.

\section{Testing of Hypothesis No: 4.}

Ho: Beggars are eager to suggest their children to adopt the same profession in future.

Chi-Square Tests

\begin{tabular}{|c|c|c|c|}
\hline & Value & df & Asymp. Sig. (2-sided) \\
\hline Pearson Chi-Square & $12.785^{\mathrm{a}}$ & 12 & .385 \\
Likelihood Ratio & 13.233 & 12 & .352 \\
Linear-by-Linear Association & .557 & 1 & .456 \\
N of Valid Cases & 140 & & \\
\hline
\end{tabular}

a. 10 cells $(50.0 \%)$ have expected count less than 5 . The minimum expected count is .55 . P value : 0.385

By eyeballing the observed frequencies in the cross tabulation matrix, it appears that beggars are eager to suggest their children to adopt the same profession in future. Interestingly, the findings of the study reflect that the begging is now becoming a profession in Karachi and the majority of the beggars are satisfied with the profession and willing to transfer the same profession to their next generation. This result concludes and accepts our null hypotheses that there is a statistically significant association between beggars satisfaction and to suggest their children for adopting the same profession in future.

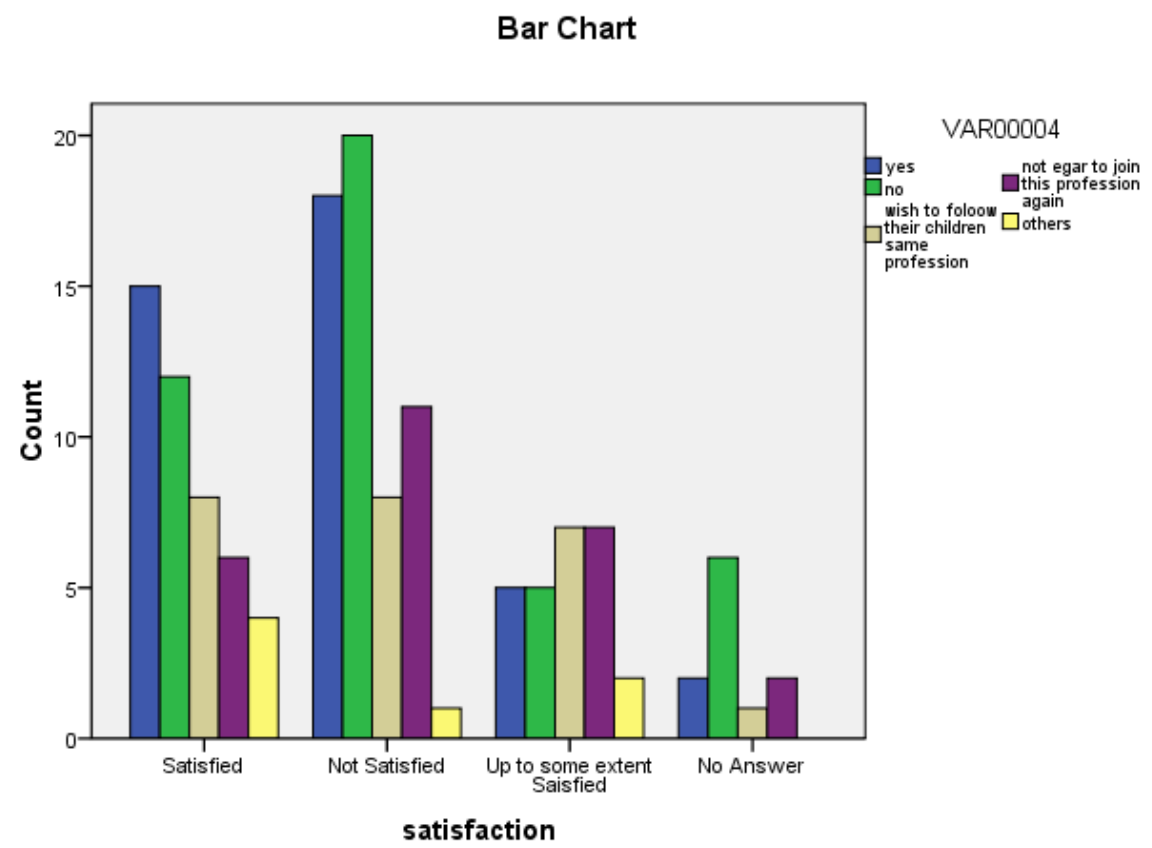

Figure:4

This research has been initiated to focus on socio - cultural determinants of begging with reference to Karachi city. The researcher had used the different variable like socio-economic status, age, gender, residential arrangement, and per day income to understand the begging phenomenon wisely and to address the behindhand factors of this 
complex issue. About one hundred and forty street beggars (140) were interviewed; using self-administered questionnaires to collect each respondent's data.

It is noticed that the demographic characteristics like male population, female population, gender ratio, and household size are significantly associated with socio-economic status. (See table 1)

It is revealed that majority of the respondents were Female beggars $(41.5 \%)$.Keeping in view the Islamic perspective and Pakistani culture, male members of the family are responsible for financial support of the family. In the present research, it was noticed that female beggars were taking the financial burden in society as beggar. This results are quite resembled with the study of Aliya Bano (2013) found it as a "gender issues which need to be addressed through legal interventions."

The study conducted by Lowicki (2002) found that the "Household poverty is the key motivating reason for children to work as a beggar and their earnings are treated as the great support for their family's survival". This study results showed that the majority of the respondents were married (35.9\%) and having children (20.4\%).

As far as the residing conditions, interestingly, this research showed that (47.2\%) beggars have their own property, mainly in slum areas or extent of informal settlements in urban peripheries (26.8\%). Approximate $28.9 \%$ of the respondents were stated that they living as a tenant in a rented house whereas others are living with relatives $22.5 \%$ respectively. These results have also confirmed the research of a familiar study, conducted by Ali. et al. (2004) in the Pakistani context. Another interesting and distressing finding is that $27.7 \%$ of beggars, who belongs to rural background, have completed their Matriculations. This result indicates that there is a missing link between quality of education and the economical consumption of the students.Hence, this study found that there is a strong connection in different variable like internal migration, poor quality of education, low wages or joblessness, and marital status, which pushed the respondents to enter in informal economy as survival strategy.

Furthermore, it was also noticed with great concerns that a high percentage of the respondents were reported that they worked as Part-time beggars (36.4\%), whereas, $25.7 \%$ beggars were worked as full time job .In this regard, $18.6 \%$ beggars were used their small or weak children as a successful begging tactic to get the sympathy of the people. This result indicates that the demonstration of the weak children is a standard practice for obtaining charity.

As far as the job satisfaction is concerned,$(41.4 \%)$ of the respondent declares that they did not satisfied with this profession, however remaining $59 \%$ of the respondent did satisfied up to some extent with the profession. More importantly, it was declared that a vast majority has their own house in the slum areas of the city; this indicates the weak governance or ill legal systems of living.

The results of the study found significant relationship between begging as a part time profession. Data also revealed that most of the beggars were belongs to rural background and migrated to Karachi for and had chosen begging. Almost $30 \%$ of the respondents were earned Rs: $550-700$ per day.

\section{Conclusions}

This study pointed out that homelessness, poverty; unemployment and family rejection are the connecting factors which are directly squeezed with begging. While, weak governance and the absences of Governmental check and balance and policy implementation about working on the street are linked to promote the begging culture in Karachi comfortabilly.Simillarly, there is a strong social-political network regarded as a key component in the life of street beggars which provide a lot of support, protection and facilitate them in their personal, social, economic life as viewed by the present study. The researchers observed serious lapses in the maintenance of effective check and balance systems on the streets. This situation helps and facilitates the beggars in performing their job. It can be concluded that bagging should be considered as a national problem and necessary policies must be designed for its reduction.

\section{Recommendations}

On the basis of the above-mentioned analysis, this research suggests that:

- It is revealed that the absence of legal earning opportunities and weak police monitoring system are listed as exclusive factors for beggars' involvement in criminal activities in Karachi. 
- This research endorses that for controlling street begging and its contributing factors, a holistic approach is needed. Policymakers and public authorities may implement multi-dimensional interventions on the basis of socio-religious and psycho-economic factors.

- This study strongly recommends that the government should take necessary vigilant, preventative and responsive steps for the elimination of all types of begging especially criminal beggars and powerful mafia groups from society.

- There is a strong need to set or design the "eligibility criteria" for donation or charity through appropriate urban charity policy. There is a need to design a proper system for the welfare of genuinely deserving people in every community (Muhalla) or union council or town level. Furthermore, through proper monitoring and collecting weekly charity or donation from the community through Social Workers, support the needy people at their doorstep in the same community decently.

- Moreover, Social Security system should put more emphasis on social insurance and social assistance programs for the socially disadvantage people for their social cohesion at local community level with proper record of genuine or deserving people is also needed in the city.

- Comprehensive policies and effective policing system and accurate Statistical information are required to address this issue within proper legislative contexts. In this connection, Beggars would not be permitted to work in the streets.

- Furthermore, necessary measures should be taken to ban on beggars migrating from one city to another city. Media campaigns can play a vital role in discouraging the begging practices.

- More rigors, empirical researches are needed for better understanding of the phenomennah.

\section{References:}

1. Abdallah Jacob Seni (2016), "The Experiences and Perceptions Encountered by Young Carers of Visually Impaired Adult Beggars in Tanzania: Implications for access to basic education". European Journal of Education Studies. Volume 2, Issue 1, pp.: 91-109.

2. Abbasi Aliya, (2013), An Explication of the Paradox of Street Working Children (SWC) with SpecialReference to Pakistan, International Journal of Humanities and Social Science Vol. 3 No. 20; pp: 5160.

3. Agbola SB, Olatubara CO (2004). "Land use Planning" in Tunde Agbola (ed) Readings in Urban and Regional Planning. Nigeria: Macmillan Nigeria Publishers Ltd.

4. Adedibu, A.A. \& Jelili, M.O. (2011). Package for controlling street begging and rehabilitating beggars and the physically challenged in Nigeria: Paper for policy consideration. Global categories of street beggars and factors influencing street begging. Journal of Human Social Science, Global Journals Inc. (USA), 11(1): pp.17-24. Available on:

https://globaljournals.org/GJHSS_Volume11/2_Package_for_Controlling_Street_Begging_and_Rehabilitati ng.pdf

5. Ahamdi H.(2010) "A study of beggar's characteristics and attitude of people towards the phenomenon of begging in the city of Shiraz, Journal of Applied Sociology, 39 (3):135-148.

6. Alan, E. (2010). "Use of recreation as an adjunctive therapy in medical treatment and rehabilitate of beggars". A paper presented at the annual conference of CASSON, Kano, 2012. Pg. 4-12.

7. Ali, M., Shahab, S., Ushijima, H., \& Muynck, A. d. (2004). Street children in Pakistan: A situation analysis of social conditions and nutritional status. Social Science \& Medicine, 59, 1707-1717.

8. Baltazar M.L. Namwata* Maseke R. Mgabo , Provident Dimoso(2012 ), Feelings Of Beggars On Begging Life And Their Survival Livelihoods In Urban Areas Of Central Tanzania International Journal Of Physical And Social Sciences, Vol .2(7) Pp:306-322

9. Balachova, T., Bonner, B. L., \& Levy, S. (2009). Street children in Russia: Steps to prevention. International Journal of Social Welfare, 18(1), 27-44.

10. Balogun, A. (2012), New forms of begging on Lagos Street. The Punch Newspaper, $17^{\text {th }}$ March 2012.

11. Benítez, Sarah Thomas de. 2001. What Works in Street Children Programming: The JUCONI Model. International Youth Foundation, USA. Retrieved from: http://cfsc.trunky.net/_uploads/Publications/2.What_Works_in_Street_Children_Programming_The_Juconi Model. on Jan 15, 2017.

12. Broun, (2010). Idiege, B., Ube, M. and Bisong, M.D counseling youth Against drugs abuse: Implication for human development. Conference proceeding. 34th Annual SCASSON conference. Pg. 20-28. 
13. Boaten, A.B. "An Examination on the Phenomenon of Street Children in Selected Communities in Accra (Ghana", A Dissertation Presented to the Faculty of the College of Education of Ohio University in Partial Fulfillment of the Requirements for the Degree Doctor of Philosophy. (Ohio: Ohio University Press, 2006)

14. Bose, R. and Hwang, S.W. (2002). Income and spending patterns among panhandlers. Canadian Medical Association Journal 167(5): 477-479.

15. Collins, D. and Blomley, N. (2003). Private needs and public space: politics, poverty, and anti-panhandling by-laws in Canadian cities. In Law Commission of Canada (Ed.), New perspectives on the public-private divide, Vancouver: UBC Press. Page: 1.

16. Constitution of Pakistan (2010), Article 38, Clauses (c) and (d).

17. Chukwulobe, C. (2011) "Street Begging and its prevalence in Niger State". Unpublished project Pg. 2-15.

18. City District Government Karachi (2007). Karachi strategic development plan 2020. Master plan group of offices, City District Government of Karachi (CDGK); 2007.

19. Dhruvasan, A.R. (1963). Is this a part of religion? Social Welfare 10 (9), 10-12.

20. Europen Commssion.(2012),.Report for the study on typology and policy responses to child begging in the EU” Pp:27-41.

21. Fives, A; Kennan, D; Canavan, J; Brady, B and Cairns, D (2010), Study of Young Carers in the Irish Population. Dublin: Government Publications.

22. Frankel RM, Quill TE, McDaniel SH (2003): The Biopsychosocial Approach: Past, Present, Future.University of Rochester Press, Rochester, NY, P: 67.

23. Government of Pakistan (2010), Population CENSUSs organization, Statistics division, Minister of Economic affairs and Statistics," Government of Pakistan; 2010. (Online) (Cited 2010 Dec 13). Available from URL: http://www.statpak.gov.pk/depts/pco/

24. Gurav, R.B., 2015. Socio-Demographic Profile and Health Problems of Beggars in an Urban Area. International Journal of Scientific Research, 4(1): 420-422.

25. Ghimire Loknath(2014) "Being on the Street Causes, Survival Strategy and Societal Perception An Empirical Study of Street Children in Kathmandu", Faculty of Social Science, University of Nordland, Norway.

26. Hanchao Lu ,(2005)Street Criers: A Cultural History of Chinese Beggars the American Historical Review, Volume 111, Issue 4, 1 October 2006, Pages 1149-1150,https://doi.org/10.1086/ahr.111.4.1149

27. Hasan A, Mohib M.(2003) Understanding slums: Case studies for the global report on human settlements. City Reports for the UNHSP Global Report 2003 for the Development Planning Unit, University College London, United Kingdom; The case of Karachi, Pakistan. Pp: 4-66 http://arifhasan.org/wpcontent/uploads/2002/06/AH84-Reporting_on_slums.pdf

28. ILO(2004) , "A rapid assessment of bonded labour in domestic work and begging in Pakistan",

29. Jelili M.O. 2006. "Environmental and Socio- economic Dimensions of Begging in Ilorin and Ogbomoso. Unpublished M.Tech dissertation, Department of Urban Regional Planning, Ladoke Akintola University of Technology, Ogbomoso, Nigeria. P: 4

30. Jelili, M.O. (2013) "Street Begging in Cities: Cultural, Political and Socio-Economic Questions". Global Journal of Human Social Science (Sociology and Culture) Volume 13 Issue 5 Versions 1.0 Year 2013. ISSN: 2249-460x \& Print ISSN: 0975-587X.

31. Johnsen, S.; Fitzpatrick, S. (2008). "The use of enforcement to combat begging and street drinking in England: a high risk strategy?" European Journal of Homelessness.Vol 2, pp. 191-204.

32. Johnny, J. (2008). "In tough times, panhandling may increase in Oklahoma City". The Oklahoma.

33. John, O. (2010) Street begging a menace. Available on: https://www.scribd.com/document/46783864/Romanism-A-Menace-to-the-Nation . (assessed on 21 June 2015)

34. Khan, J-(2013), Problem of beggars: A case study. International journal of management and social sciences Research, 2(120, 67-74.

35. Khan, J. H., Menka\&Shamshad (2014). Socio-economic causes of begging, International Research Journal of Human Resources and Social Sciences, Vol.1, No.3: 37-52.

36. Kaushik,A(2014).Rights of Children: A Case Study of Child Beggars at Public Places in India" Journal of Social Welfare and Human Rights, Vol. 2, No. 1, pp. 01-16.

37. Lynch, P. (2005)., "Understanding and responding to begging". Melbourne University Law Review. Available at: http://www.austlii.edu.au/au/journals/MULR/2005/16.html (accessed on 21 July 2015)

38. Lowicki, J. (2002). Fending for themselves: Afghan refugee children and adolescents working in urban Pakistan. New York: Women's Commission for Refugee women and children. 
39. Mander, Harsh (2009, January 25), the war against begging, The Hindu.

40. Malone, A. (2009)., "The Real Slumdog Millionaires: behind the cinema fantasy, mafia gangs are deliberately crippling children for profit". Daily Mail. 24 Jan. Available at: http://www.dailymail.co.uk/news/worldnews/article-1127056/The-real-Slumdog-Millionaires-Behindcinema-fantasy-mafiagangs-deliberately-crippling-children-profit.html (accessed on 21 June 2015)

41. Namwata, B.M.L., Mgabo, M.R. \& Dimoso, P. (2012, June). Categories of street beggars and factors influencing street begging in central Tanzania. African Study Monographs, 33(2): 133-143.

42. Nafees Asaad Ahmed, Kausar Saeed and Zafar Fatmi ,(2012)," Situation analysis of child labour in Karachi, Pakistan: a qualitative study. Journal of Pakistan Medical Association, 62(10), 1075-1082. Available at: http://ecommons.aku.edu/pakistan fhs mc chs chs/139

43. O. A. Fawole, D. V. Ogunkan, and A. Omoruan (2010). The Menace of Begging in Nigerian cities: A Sociological Analysis. International Journal of Sociology and Anthropology Vol. 3(1), pp. 9-14.

44. Rahman, M. (2009)., "Bangladesh plans jail threat to deter beggars". The Guardian. http://www.guardian.co.uk/world/2009/apr/03/bangladesh-jailbeggars. [Accessed 19 June 2015].

45. Ogunkan, D.V. and O.A. Fawole,( 2009)., "Incidence and socio-economic dimensions of begging in Nigerian cities: The case of Ogbomoso". International NGO Journal., 4(12): pp.498-503. Available on: http://www.academicjournals.org/journal/INGOJ

46. Olawale, S.G. (2007). Aetilological perception of alms-begging behaviours amongpeople with special needs in Oyo State: Counselling towards solution. The Counsellor,23, (1), 44- 53.

47. Onoyase, A. (2010). "Effective methods of combating street begging in Nigeria as perceived by panhandlers." Studies on Home and Community Science, 4, 109-114.

48. Rahman, M. (2009)., "Bangladesh plans jail threat to deter beggars". The Guardian. http://www.guardian.co.uk/world/2009/apr/03/bangladesh-jailbeggars. [Accessed 19 June 2015].

49. Sabina (2010) "The Condition of Bangladesh Beggers", available at

50. http://gurumia.com/2010/04/12/the-condition-of-bangladesh-beggers/ (assessed on 21 June 2015)

51. Saini, V. (2009)., "Beggary: Issue and Challenge for the City Beautiful, Chandigarh". available at: http://www.articlealley.com/article_857569_63.html (assessed on 24 June 2015)

52. Tatek A. (2009).' Sikalla': the survival strategies of Ethiopian chiled beggers. In s Ege, H. aspen, B.Tefera , and S Bekele.(eds.). Proceeding of the 16th international conference of Ethiopian studies (PP10331044), Trandihim: Norway.

53. Tambawal, M.U (2010). The Effects of Street Begging on the National Development: Counselling Implications. A Paper Presented at the 1st national Conference of the Counseling Association of Nigeria (CASSON) Katsina State Chapter from 7th- 10th June 2010. Faculty of Education and Extension Services, Department of Educational Foundations, Usmanu Danfodiyo University Sokoto.

54. Tanvir (2011) "Beggars declassified" available at: http://stolenemotions.wordpress.com/2011/05/18/beggars-declassified/ (accessed on 20-4-15)

55. Thakker, Y. Gandhi, Z., Sheth, H., Vankar, G. K. \& Shroff, S. (2007). Psychiatry Morbidity Among Inmates of the Beggar Home. International Journal of Psychosocial Rehabilitation, 11(2), 31-36.

56. Tripathi, S. C. and Arora, Vibha (2010), Law Relating to Women and Children, Allahabad: Central Law Publications. P:354-356.

57. Ibib, P:354.

58. UN-HABITAT (United Nations Human Settlement Programme) (2007): Enhancing urban safety and security: Global report on human settlements 2007. London, Sterling, VA. Pg:76, Available from: https://www.un.org/ruleoflaw/files/urbansafetyandsecurity.pdf[accessed Oct 2, 2008]

59. United Nations Children's Fund. (UNICEF). (2006).Children first: Children living and working on the streets]. Available from: http://www.unicef.org/turkey/dn_2006/_cp43.html [accessed Oct 2, 2008].

60. Usoro, H. et al (2007), The prevalence of street begging in Cross River State: Implication for Counselling and Vocational Counselling. (Paper presentation at the CASSON Conference 2007. 5-12).

61. Woodhead, Martin (1998). Children's Perspectives on their Working Lives: a participatory study in Bangladesh, Ethiopia, The Philippines, Guatemala, El Salvador and Nicaragua. Radda Barnen, Stockholm, Sweden . Retrived from : http://oro.open.ac.uk/28493/ on 13-6-2015.

62. Yilmaz, H. B and Dülgerler, S. Children who work in the Street in Izmir, Turkey. (Izmir: Ege University, Izmir, 2011), Pg 129-144.

63. Yusuf A. Bell M. B, Jarimi M, Ahmed S. Ogungbade O.K, J. A. Omotosho, AlHassan. Y. S(2012), Patterns of Street-Begging, Support Services and Vocational Aspirations of People Living With Disabilities in Ilorin, Nigeria,Research on Humanities and Social Sciences, Vol.2, No.5,pp:115-120. 